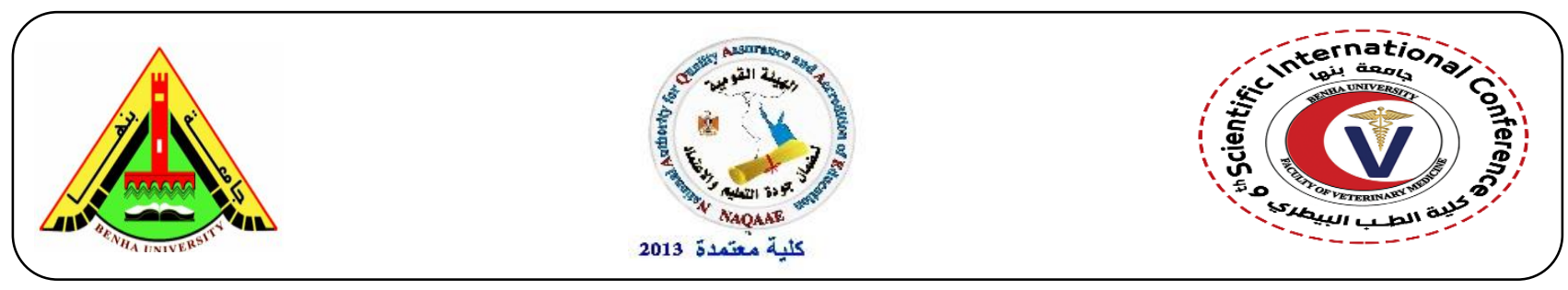

\title{
prevalence of Salmonella and Escherichia Coli Organisms as Bacteriological Hazards in some Meat Products
}

Saad, M.S., Hassan, M. A, Abou El Ros, Nahla, A. and Abou Arayes, Walaa A.

Fac.Vet. Med. Food Hygiene and Control Department.

\section{A B S T R A C T}

Meat is considered an important source of proteins, essential amino acids, B complex vitamins and minerals. Due to this rich composition, it offers a highly favorable environment for the growth of pathogenic bacteria.

A total of 45 random samples of meat products represented by beef kofta, burger and luncheon (15 of each). The weight of each sample was $10 \mathrm{gm}$ collected randomly from different supermarkets at Meonofia governorates. The incidences of E-coli in the examined samples of meat products were $46.67 \%, 40 \%$ and 26.67 for beef kofta, burger and luncheon, respectively. Moreover, the isolated serotypes of $E$-coli from the examined samples of meat products were $\mathrm{O}_{26}: \mathrm{H}_{11}, \mathrm{O}_{111}: \mathrm{H}_{4}, \mathrm{O}_{114}: \mathrm{H}_{21}, \mathrm{O}_{124}$, $\mathrm{O}_{55}: \mathrm{H}_{7}, \mathrm{O}_{119}: \mathrm{H}_{6}, \mathrm{O}_{127}: \mathrm{H}_{6}$ and $\mathrm{O}_{128}: \mathrm{H}_{2}$ with various percentages. The incidences of Samonellae in the examined samples of meat products were $26.67 \%$ and $13.13 \%$ for beef kofta and burger, respectively. While, all examined samples of beef luncheon were free from Salmonellae. Moreover, the isolated serotypes of Salmonella from the examined samples of beef kofta and burger were S. Typhimurium, S. Enteritidis and S. Muenster.

It is clearly demonstrating that there is high bacterial load beside a relatively high rate of pathogens (E. coli and Salmonellae), this may be due to mishandling and the negligence of hygienic aspects either at production levels where most workers did not have medical certificates or selling meat with expired dates. Therefore, it was concluded that E. coli and Salmonellae are meat-borne pathogens of public health important.

Key words: Samonellae, E-coi, kofta, burger, luncheon.

( http://www.bvmj.bu.edu.eg)

(BVMJ-34(3): 150-157, 2018)

\section{INTRODUCTION}

Meat and meat products are the most of digestable food of highly nutritive value for human being as they are significant sources for protein, fat, essential amino acids, minerals, vitamins and other nutrients (Biesalski, 
2005).Otherwise, they are considered as an ideal culture medium for growth of many organisms because of the high moisture, the high percentage of nitrogenous compounds, plentiful supply of minerals, some fermentable carbohydrates (glycogen) and of a favorable $\mathrm{Ph}$ for most microorganisms(Al-Mutairi, 2011). The primary habitat of Salmonellae is intestinal tract of animals and humans. In recent years, $E$. Coli has become recognized as a serious food born pathogen and has been associated with numerous out breaks of disease in the disease in UK, Japan and USA (Scotter et al ,2000). Escherichia coli includes a variety of different types that range from avirulent commensally strain that are present in normal intestinal flora to highly virulent strains that cause a variety of severs infections in both humans and animals.

Over 700 antigenic types or serotypes of $E$. coli have been recognized based on $\mathrm{O}, \mathrm{H}$ and $\mathrm{k}$ antigen. Their pathogenicity is considered to be mainly by specific virulence factors such as adhesions, invasions, toxins and capsule (Kaper et al., 2004). Therefore, this study was planned out to evaluate the bacteriological status of meat products by isolation and identification of Escerichia

Coli and Salmonellae from examined samples of meat

products.

\section{MATERIAL AND METHODS}

\section{Collection of Samples:}

45 random samples of meat products represented by beef kofta, burger and luncheon (15 of each). The weight of each sampler was 10 gm which were collected randomly from different supermarket at meonofia governorates. The examined samples were kept in sterile plastic bags and preserved in ice box. All the examined samples were subjected to bacteriological examination to isolate $E$-coli and Salmonellae.

2.Preparation of samples (APHA 1992):

Ten grams of examined samples were aseptically transferred to aseptic blender jar and $90 \mathrm{ml}$ of $0.1 \%$ sterile buffered peptone water were to $(0.1 \%)$ were aseptically added to the content of jar. Each sample was then homogenized in the blender at $2000 \mathrm{rpm}$ for 2 minutes to provide a homogenate, from which tenth-fold serial dilution were prepared.

3.Isolation of food borne pathogens;

1.Isolation and identification of E. Coli (McFadden 2000):

The technique recommended by McFadden 2000 by using (E.M. B) Eosine Methylene Blue agar media. Suspected colonies for E. Coli were morphologically, biochemically and serologically identified.

Serotyping of E. coli:

E. coli isolates were serologically identified according to Kok et al. (1996) by using rapid diagnostic E. coli antisera sets (DENKA SEIKEN Co., Japan) for diagnosis of the Enteropathogenic

types.

\section{Isolation and identification of Salmonellae:}

The technique recommended by ISO, (2002) by using Xylose lysine Desoxychoclate (XLD) agar media. Suspected colonies for Salmonella were morphologically, biochemically and serologically identified.

Serotyping of Salmonella:

Salmonella were serologically identified according to Kauffman - White scheme 
(Kauffman, 1974) for diagnosis of the Salmonella types.

\section{RESULTS:}

Result achieved in tables (1) indicated that the incidence of $E$. coli in examined samples of meat products were $46.67 \%, 40 \%$ and $26.67 \%$ for beef kofta, burger and luncheon, respectively. While $E$. coli failed to be detected in the examined samples of beef luncheon. The serologically identified $E$. coli isolates in the

examined samples of beef kofta were $\mathrm{O}_{26}: \mathrm{H}_{11}$ (13.33\%), $\mathrm{O}_{111: \mathrm{H}_{4}}(6.67 \%), \mathrm{O}_{114}: \mathrm{H}_{21}$ (6.67\%), $\mathrm{O}_{55: \mathrm{H}_{7}}(6.67 \%), \mathrm{O}_{119}: \mathrm{H}_{6}(6.67 \%)$ and $\mathrm{O}_{128}: \mathrm{H}_{2}$ $(6.67 \%)$, while in examined samples of beef burger were $\mathrm{O}_{26}: \mathrm{H}_{11}(13.33 \%), \mathrm{O}_{111}: \mathrm{H}_{4}(6.67 \%)$, $\mathrm{O}_{124}(6.67 \%), \mathrm{O}_{127}: \mathrm{H}_{6}(6.67 \%)$ and $\mathrm{O}_{128}: \mathrm{H}_{2}$ (6.67\%).

The results in table (2) indicated that the incidence of Salmonellae in examined samples of meat products were $26.67 \%$ and $13.33 \%$ for beef kofta and burger, respectively and the serologically identified Salmonella isolates in the examined samples of beef kofta were $S$. Typhimurium (13.33\%), S. Enteritidis (6.67\%) and S. Muenster (6.67) for beef kofta. Moreover, in the examined samples of beef burger were $S$. Typhimurium (6.67\%) and $S$. Enteritidis (6.67\%). While Salmonellae failed to be detected in the examined samples of beef luncheon.

Table (1): Incidence and serotyping of Enteropathogenic E. coli isolated from the examined samples of meat products $(n=15)$.

\begin{tabular}{|c|c|c|c|c|c|c|c|}
\hline \multirow{2}{*}{$\begin{array}{l}\text { E. coli } \\
\text { strains }\end{array}$} & \multicolumn{3}{|c|}{ Kofta } & \multirow{2}{*}{$\begin{array}{r}\text { Burger } \\
\%\end{array}$} & \multicolumn{2}{|c|}{ Luncheon } & \multirow{2}{*}{$\begin{array}{c}\text { Strain } \\
\text { Characteristics }\end{array}$} \\
\hline & No. & $\%$ & No. & & No. & $\%$ & \\
\hline $\mathrm{O}_{26}: \mathrm{H}_{11}$ & 2 & 13.33 & 2 & 13.33 & 1 & 6.67 & EHEC \\
\hline $\mathrm{O}_{111}: \mathrm{H}_{4}$ & 1 & 6.67 & 1 & 6.67 & 1 & 6.67 & EHEC \\
\hline $\mathrm{O}_{114}: \mathrm{H}_{21}$ & 1 & 6.67 & - & - & - & - & EPEC \\
\hline $\mathrm{O}_{124}$ & - & - & 1 & 6.67 & - & - & EIEC \\
\hline $\mathrm{O}_{55}: \mathrm{H}_{7}$ & 1 & 6.67 & - & & 1 & 6.67 & EPEC \\
\hline $\mathrm{O}_{119:} \mathrm{H}_{6}$ & 1 & 6.67 & - & - & & & EPEC \\
\hline $\mathrm{O}_{127}: \mathrm{H}_{6}$ & & & 1 & 6.67 & 1 & 6.67 & ETEC \\
\hline $\mathrm{O}_{128:} \mathrm{H}_{2}$ & 1 & 6.67 & 1 & 6.67 & & - & ETEC \\
\hline Total & 7 & 46.67 & 6 & 40 & 4 & 26.67 & \\
\hline
\end{tabular}


Table (2): Incidence and serotyping of Salmonella isolated from the examined samples of meat products $(\mathrm{n}=15)$.

\begin{tabular}{llccccc}
\hline \hline \multirow{2}{*}{$\begin{array}{c}\text { Salmonella } \\
\text { serotypes }\end{array}$} & \multicolumn{2}{c}{ Kofta } & \multicolumn{2}{c}{ Burger } & \multicolumn{2}{c}{ luncheon } \\
\cline { 2 - 7 } & No. & $\%$ & No. & $\%$ & No. & $\%$ \\
\hline S. Enteritidis & 1 & 6.67 & 1 & 6.67 & - & - \\
\hline S. Muenster & 1 & 6.67 & - & - & - & - \\
\hline $\begin{array}{c}\text { S. } \\
\text { Typhimurium }\end{array}$ & 2 & 13.33 & 1 & 6.67 & - & - \\
\hline \multicolumn{1}{c}{ Total } & 4 & 26.67 & 2 & 13.33 & - & - \\
\hline \hline
\end{tabular}

\section{DISCUSSION}

Foodborne illnesses caused by E. Coli and Salmonellae species represent a great public health problem worldwide. These pathogens are transmitted mainly through consumption of contaminated food and the presence of these organisms in meat and raw meat products has relevant public health implications (Normanno et al., 2007 and Sousa, 2008). It is well established fact that the main source of transmission for pathogenic bacteria is contaminated food, it is considered as the major cause of enteric diseases in developing countries and the major cause of mortality and morbidity. (Gunasegaran et al 2011).

The current results of the incidence of $E$. coli in the examined samples of beef kofta were lower than those obtained by Mohamed (2006) (4\%), Nadim (2016) (28\%) and Mohamed (2016) $(12 \%)$ but similar to those obtained by Abdalla and Hassan (2004) (40\%). The current results of the incidence of $E$. coli in the examined samples of beef burger were higher than those obtained by Abou_Hassien (2004) (64\%) and Fathi et al(1994) (77.78\%) and lower than those obtained by Hassan (2007) (15\%), Mohamed (2009) (13.3\%), Mewafy (2012) (10\%) and Ahmed (2015) (13.2\%), but similar to those obtained by Zaki (2002) (35\%), and Hassan (2012) (32.5\%).The current results of the incidence of E.coli in the examined samples of beef luncheon were higher than those obtained by Abou-Hussien (2004) (40\%),but lower results were obtained by Abd-EL wahhab (2017) (16\%) ,Ahmed (2017) (2.5\%), Reyad(2015) (16\%), Abd-EL-Hag (014) (4\%), Hassan (2007) (7.5\%) and Elewie (2003) (4\%). but similar to those obtained by Attia (2016) (30\%).

While the current results of the incidence of Salmonellae in the examined samples of beef kofta were lower than those obtained by Mohamed (2009) (8\%), Nadim (2016) (8\%). The current results of the incidence of Salmonellae in 
the examined samples of beef burger were lower than those obtained by Mohamed (2009) (4\%) and ouf (2001) (5\%), higher than those by Mousa (2014) (20\%), Yehia (2015) (20\%). It failed to be isolated by Nadim (2016). While Salmonella failed to be detected in examined samples of beef luncheon similar to those obtained by Ouf (2001), Eleiwa (2003) and Abou Hussin (2014), but salmonellae could be detected in beef luncheon by Said (2014) (4\%) and Yahia (2015) (4\%).

Further than, $\mathrm{O}_{128}$ serotype of E. Coli is called Enterotoxigenic E. Coli (ETEC), while strain cause desentry like syndrome $\left(\mathrm{O}_{124}\right)$ are known as Enteroinvasive E. Coli (EIEC). While strains causing haemoragic colitis $\left(\mathrm{O}_{111}\right)$ are recognized as Enteroheamoragic E. Coli (EHEC). Bryan (1982). In general, EPEC strains are the major cause for many infantile diarrhea, in typical cases, symptoms appear within 12 to 36 hours. Clinically, EPEC illness is characterized by fever, nausea, vomition and watery stools, which occasionally contain mucous, but without gross blood (Toledo et al., 1983). Furthermore, EPEC was implicated in cases of gastroenteritis, cystitis, colitis, pyelonephritis, and peritonitis as well as food poisoning outbreaks (Doyle, 1990). Therefore, EPEC showed to be the first bacterial cause of diarrhea in infants and its proportion may reach 54\% (Varnam ant Evans, 1991).

Salmonellosis is a great problem and one of the most important food born disease. Mishandling in preparation of food of animal origin was the major reason for the outbreak of salmonellosis (e.g. 25 of 35 registered out breaks in 1986 were related to food of animal origin) (Rachmanin and Koulikouskii, 1990). The number of human cases of salmonellosis increased due to serious hygienic defeciency in food technology during processing, production and storage of food as well as due to poor hygiene of personal working (Koutikoyski and Kasijanenko, 1991).

Therefore, the products which contaminated by E. Coli and Salmonellae are hazards for consumers.

\section{REFERENCES}

Abd EL wahhab -Nesma, H. (2017): "Incidence of some pathogene bacteria in poultly products" M. V. Sci Thesis (food hygiene \&control), Fac. Vet. Med. Alex Univ. Egypt.

Abd EL-Hak -Marwa, M. R. (2014): "Molecular Characterization of pathogenic E- Coli isolated from meat and their products.", M.V.Sci Thesis (Bacteriology,mycology and Immunology) Fac. Vet. Med.Suez Canal Univ.Egypt.

Abdalla,W. and Hassan,A.A.(2000): Sanitary status of some ready to eat meat meals in cairo and Giza Governorates.J.Egypt. Vet. Med, Assuit,60(7): 95. Egypt.

Abou Hussein-Reham, A. A. (2004): "Microbial Evaluation of Some Meat Products", M. V. Sci. Thesis (Meat Hygiene), Fac. Vet. Med. Zagazig Univ. (Benha Branch). Egypt.

Ahmed- Aya, M. E. (2015): "Prevalence of some food born bacteria isolated from meat and meat products in Kaliubiya governorate.", M.V.SciThesis (bacteriology\&mycology and immunology) Fac. Vet. Med. Banha Univ. Egypt.

Ahmed, M. A.E.B. (2017): "Prevalence of salmonella, E. Coli and campylobacter in raw chicken products.", M. V. Sci. Thesis (food hygiene \& control) Fac. Vet. Med. Alex Univ. Egypt. 
Al-Mutairi, M. F. (2011): "The incidence of Enterobacteriaceae causing food poisoning in some meat products". Advanced J. Food Science and Technology, 3 (2):116-121.

American Public Health Association "APHA" (1992): Compendium of Methods for the Microbiological examination of Foods.

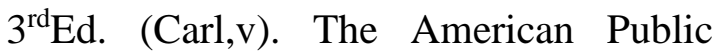
Health Association, Washington, D.C.

Attia- Aya, K. Z. (2016): "Molecular study on multiple antibiotic resistance of some bacteria isolated from food of animal origin in Egyptian markets.", M.V. SciThesis (bacteriology, mycology and immunology) fac. Vet. Med.Beni Suef Univ. Egypt.

Biesalski, H. K. (2005): "Meat as a component of a healthy diet.Are there any risks

Bryan,F.L.(1982): Diseases transmitted by foods. Textbook, $2^{\text {nd }}$ Ed.HHS. Publ. Services, public health services, center for disease control, Atlanta, Georgia 30333 USA.

Cui S. (2004): Detection and characterization of Escherichia coli $\mathrm{O}_{157}: \mathrm{H}_{7}$ and Salmonella in food .ph.D. Thesis, Fac. Graduate School, Univ. Maryland, College park.USA.

Doyle, M.P. (1990): Pathogenic E. coli. The Lancet 336:1111-1115.

Eleiwa, N. Z. H. (2003): "Effect of chemical preservatives on food poisoning bacteria in some locally manufactured meat products". Ph. D. Thesis (Meat hygiene), Fac. Vet. Med., Zagazig Univ., (Benha Br.).

Fathi, s, El-Kateib ,T.;Mostafa ,S. and Hassanin ,K.(1994): "Salmonella and
Enteropathogenic Escherichia coli in some locally manufactured meat product .Assiut vet. Med.J.,31:190.

Gunasegaran, T.; Rathinam, X.; kasi,M.; Sathasivam.; Sreenivasan, S. and Subramaniam, S.(2011): "Isolation and Identification of Salmonella from curry samples and its sensitivity to commercial antibiotics and aqueous extracts of camellia sinensis (L.) and Trachyspermum ammi (L.).

Hassan, Z. H. (2012): Conventional and rapid detection of Escherichia coli and Staphylococcus aureus in some meat products. P.H.D Thesis (Meat hygiene) Fac. Vet. Med. Menofia University, Sadat branch.

Hassan, Z. H. (2007): Studies on food poisoning microorganisms in some meat products. M. V. Sc. Thesis (Meat hygiene) Fac. Vet. Med. Menofia University, Sadat Branch. Egypt.

International Organization for standardization "ISO" (2004): Microbiology of food and animal feeding stuff -Horizontal methods for the detection and enumeration of Enterbacteriaceae No .11291-1.

ISO 6579 (2002): "Microbiology of food and animal feeding stuffs- horizontal method for the detection of Salmonella spp". International standard. ( $4^{\text {th }}$ edition).

Kaper J. B.; Nataro J. P. and Harry L. T. Mobley (2004): Pathogenic Escherichia coli, Nature Reviews Microbiology, 2, 123440. Kaper, J.B. (1996): Defining EPEC, Rev Microbiol Sao Paulo 27, 130 /133.

Kauffman, G. (1974): Kauffmann white scheme. J. Acta. Path. Microbiol. Sci., 61:385. 
Kok, T.; Worswich, D. and Gowans, E. (1996): Some serological techniques for microbial and viral infections. In Practical Medical Microbiology (Collee, J.; Fraser, A.; Marmion, B. and Simmons, A., eds.), $14^{\text {th }}$ ed., Edinburgh, Churchill Livingstone, UK.

Koutikoyski, A.V. and Kasijanenko, A.I. (1991): present status of Salmonellosis in the Soviet Union,WHO collaboration center for veterinary sanitation and food hygiene,Moscow, USSR.

Marriott, N.G. (1997): Essential of food sanitation $\quad .1^{\text {st }}$ ed chapter $17 \quad \& \quad 18$ Chapman and Hall, New York.

Mewafy - Abeer (2012): characterization of Escherichia coli o157:h7 isolated frommeat and meat products. P.H.D Thesis (Bacteriology, Immunology and Mycology) Fac. Vet. Med. Cairo Unive.

Mohamed- Asmaa, Sh. A. F. (2006): "Escherichia Coli $\mathrm{O}_{157}: \mathrm{H}_{7}$ IN some meat products". M.V.Sci Thesis (food hygien \&control) Fac. Vet. Med., Cairo Unive.

Mohamed_Afaf, E.E. (2009): Different serotypes of $E$. coli and Salmonellae in some meat products and their behavior during different heat treatments and cold storage. Ph.D Thesis, Fac. Vet. Med., Cairo Univ.

Mohamed-Maha, M. O. (2009): "Incidence and levels of salmonella and some Emerging bacterial pathogens in the catering environment in Assuit.", M.V.Sci Thesis (food hygien \&control) Fac. Vet. Med. Assuit Unive.

Mohamed-Neveen,A.E. (2016): “Traceability Diarrheagenic E. coli in Meat Products with Special Reference to
Enterohaemorrhagic Strains .”, ph.D. Thesis (food hygien \&control) Fac. Vet. Med. Banha Unive.

Mousa M.M.; Ahmed,A.A.and EL-Shamy ,S.y.(2014): ): "Microbiological criteria of some meat products" Alexandria.vet sci.,42(1):83-89.

Nadim, Samaa. S. A. (2016): A comparative study on application of PCR and ELISA for detection of pathogens in some meat products with special references to public health. Ph.D., Thesis (food hygien \&control), Fac. Vet. Med. Benha Univ.Egypt.

Normanno, G., La Salandra, G., Dambrosio, A., Quaglia, N.C., Corrente, M., Parisi, A., Santagada, G., Firin, U. A., Crisetti, E. and Celano, G. V. (2007): "Occurrence, characterization and antimicrobial resistance of enterotoxigenic Staphylococcus aureus isolated from meat and dairy products". International J. Food Microbiology, 115: 290-296. or benefits if meat is avoided in the diet". Meat Science, 70: 509-552.

Ouf-Jehan, M. (2001): "Microorganisms of sanitary importance in some meat products additives". Ph. D. Thesis (food hygien \&control), Fac. Vet. Med., Cairo Univ., Egypt.

Rachmanin, p. and Koulikouskii, A. (1990): Epidemiology of Salmonellosis and preventive measures in U.S.S.R. veterinary N.7 :40-44.

Reyad, R. M. A. (2015): "Prevalence of shiga toxin-producing Escherichia coli in some beef product.", ph.D Thesis (food gygiene and control), Fac. Vet. Med.Sadat Univ.Egypt. 
Said- Faten, H. A. (2014) "Studies on cooked meat and chicken products.", M.V.Sci Thesis (food hygien \&control) Fac. Vet. Med. Banha Univ.

Scotter, S.; Aldridge, M. and Capps, K. (2000): "Validation of method for detection of $E$. coli $\mathrm{O}_{157}: \mathrm{H}_{7}$ in foods". Food Control, 11:85-95.

Toledo, M.R.F.; Alvariza, M.C.B.; Murahovschi, J.; Sramos, S.R.T. and Trabulsi, L.R. (1983): Enteropathogenic Escherichia Coli serotype and endemic diarrhea in infants. Infect. Immun.39: 586-589.

Varnam, A.H. and Evans, M.G. (1999): Food borne pathogens. An illustrated text chapter 13, pp 267 England, wolfe publishing Ltd. ISBN 07234, 1521,8.

Yahia -Samar, M. (2015): "Microbiological criteria of some meat products.", ph.D Thesis (food gygiene and control),Fac. Vet. Med. Alex Unive.

Zaki- Eman, M. (2003): "Risk assessment of ready prepared meat products". 